\title{
KEPERCAYAAN DIRI (SELF CONFIDENCE) MAHASISWA CERDAS ISTIMEWA PADA PEMBELAJARAN KLINIK
}

\section{Nofita Veronika, Rini Sugiarti dan Erwin Erlangga}

Magister Psikologi Universitas Semarang, Indonesia

Email: nvka882@gmail.com, rinisugiartipsikologi@usm.ac.id dan erwinerlangga@usm.ac.id

\section{Abstract}

The self confidence of Special Intelligent Student when being in clinical learning is very necessary because the higher of student self confidence is more competent in carrying out clinical learning properly. This is supported by a variety of learning methods that can affect the ability of critical thinking and confidence of nursing students including clinical conferences, simulations, model demonstrations, concept maps and nursing rounds, therefore clinical instructor must know well the learning methods to be used, in order to choose the right learning method in mentoring, especially in the clinical environment of special intelligent students.

In this review literature have purpose to analyze the confidence of special intelligent student on learning clinic. Focus and the summary of this journal is description of confident of special intelligent student on clinic learning. This journal use review method from some article the access through Ebsco.pro quest from year 2016 to 2020.

Keywords: confidence; special intelligent student; clinic learning

\section{Abstrak}

Kepercayaan diri mahasiswa cerdas istimewa saat berada pada pembelajaran klinik sangat diperlukan karena semakin tinggi kepercayaan mahasiswa tersebut semakin kompeten dalam melaksanakan pembelajaran klinik dengan baik. Hal tersebut didukung dengan berbagai metode pembelajaran yang dapat berpengaruh terhadap kemampuan berpikir kritis dan kepercayaan diri mahasiswa keperawatan diantaranya adalah konferensi klinis, simulasi, demonstrasi model, peta konsep dan ronde keperawatan, oleh karena itu pembimbing klinik harus mengetahui dengan baik metode pembelajaran yang akan digunakan, agar dapat memilih metode pembelajaran yang tepat dalam pembimbingan khususnya di lingkungan klinik pada mahasiswa cerdas istimewa. Penelitian ini bertujuan untuk menganalisa kepercayaan diri mahasiswa cerdas istimewa pada pembelajaran klinik. Fokus dan rumusan masalah jurnal ini adalah gambaran kepercayaan diri mahasiswa cerdas istimewa pada pembelajaran klinik. Penelitian ini menggunakan metode review dari berbagai artikel yang diakses melalui Ebsco, Pro Quest dari tahun 2016 sampai tahun 2020. Dalam penelitian ini didapatkan kesimpulan yaitu: Mahasiswa cerdas istimewa masih banyak yang memiliki kondisi psikologis yang sangat perlu kita perhatikan contohnya emosi, kepercayaan diri, hubungan sosial dengan teman 
sebaya karena itu mahasiswa cerdas istimewa sangat membutuhkan pendidikan khusus, kesempatan berkerjasama, dan pendampingan khusus. Dalam pendidikan keperawatan keyakinan/confidence merupakan variabel penting. Mahasiswa dengan tingkat kepercayaan diri yang lebih tinggi memiliki kemungkinan lebih besar untuk mengembangkan intervensi yang berhasil, karena mereka mampu menguji dan menggunakan kompetensinya dengan lebih mudah

Kata Kunci: kepercayaan diri; mahasiswa cerdas istimewa; pembelajaran klinik

\section{Pendahuluan}

Pembelajaran klinik merupakan pembelajaran aplikatif teori yang didapat dan hal yang sangat penting dalam sebuah pendidikan keperawatan (Hsu, Hsieh, Chiu, \& Chen, 2014), karena pembelajaran klinik merupakan proses belajar mahasiswa untuk menjadi seorang perawat yang professional (Mahanani, Dewi, \& Soeratri, 2014). Keutamaan dan keunggulan belajar di lingkungan klinik salah satunya adalah pembelajaran yang berfokus pada masalah nyata dari pasien-pasien yang dapat dipelajari dan di praktikkan secara langsung sehingga dapat memotivasi mahasiswa untuk berpartispasi aktif dalam pencapaian kompetensi, sedangkan pemikiran yang kritis, tindakan dan sikap profesionalisme diperankan oleh pembimbing klinik (Nursalam, 2014).

Pada Pembelajaran klinik, mahasiswa harus menghadapi tantangan baru yaitu mengelaborasi pengetahuan klinis yang berada dalam pembelajaran teori dan menerapkannya dalam penalaran klinis yang tepat, beban kerja yang lebih berat, perubahan pola hidup, mempelajari cara belajar baru pada tahap klinik, bersikap profesional terhadap pasien, dan mempelajari keadaan sosial serta belajar lingkungan baru yang berada dilahan praktik, membiasakan diri berkomunikasi efektif dengan pasien, berpikir kritis untuk menerapkan intervensi yang didapat dari hasil pengkajian sebelumnya (Sianturi, 2020). Tantangan baru ini bisa jadi mudah ataupun sulit dilaksanakan oleh mahasiswa baik mahasiswa biasa maupun mahasiswa cerdas istimewa.

Kata "cerdas istimewa" baru dikenal di tahun-tahun terakhir ini. Cerdas istimewa adalah istilah yang digunakan bagi seorang anak yang mempunyai kecerdasan luar biasa. Maksudnya, kecerdasan berada di atas rata-rata anak seusianya (Van Tiel, 2015). Menurut (Van Tiel, 2015) mengatakan bahwa kecerdasan istimewa akan menyangkut masalah intelegensi luar biasa sebagai syarat utama, disamping disyaratkan juga kreativitas yang tinggi, serta motivasi dan komitmen terhadap tugas yang tinggi. Dengan faktor-faktor itu maka kecerdasan istimewa dapat diwujudkan. Biasanya cerdas istimewa memiliki kemampuan penalaran yang lebih dibandingkan dengan anak lain, namun perlu adanya pendampingan yang tepat untuk anak yang cerdas istimewa ini.

Mahasiswa cerdas istimewa, sebagai remaja dengan potensi kecerdasan yang luar biasa diharapkan dapat mencapai sukses pada bidang akademik dan non akademik. Namun, berbagai penelitian menggambarkan bahwa remaja cerdas istimewa mempunyai psychological well-being yang tidak stabil. (Ogurlu, 2021) menjelaskan bahwa kesejahteraan psikologis siswa cerdas istimewa lebih baik jika dibandingkan siswa non 
cerdas istimewa. Hal ini disebabkan siswa cerdas istimewa cenderung mempunyai masalah psikologis lebih sedikit daripada teman sebayanya. Jika individu lebih sedikit mempunyai masalah psikologis maka diasumsikan individu tersebut lebih sejahtera secara psikologis. (Arum, 2019) menjelaskan bahwa indikator rendah kesejahteraan psikologis adalah adanya masalah psikologis, seperti, rendahnya kepercayaan diri, kecemasan, depresi, penyimpangan perilaku, dan gangguan psikiatris.

Kepercayaan diri merupakan suatu bagian dari kehidupan yang unik dan berharga karena dengan kepercayaan diri seseorang akan lebih mampu dan berani dalam menyampaikan pendapat didepan orang banyak dan lebih percaya dengan kemampuan yang dimilikinya (Indriawati, 2018) Kepercayaan diri ini sangat perlu ditumbuhkan dalam diri mahasiswa, seseorang yang memiliki kepercayaan diri akan lebih yakin untuk melakukan sesuatu melalui sikap yang tenang dan seimbang dalam situasi social (Pranowo, 2019). Semakin tinggi tingkat rasa percaya diri yang dialami, maka semakin tinggi pula motivasi berprestasi siswa dan sebaliknya (Asiyah, Walid, \& Kusumah, 2019).

Setiap mahasiswa bersaing untuk memperoleh prestasi yang sesuai dengan ekspektasi yang telah mereka tentukan. Namun, tidak semua individu dapat memperoleh prestasi belajar yang baik, bahkan tidak jarang pula seorang individu demi memperoleh prestasi yang baik, dapat melakukan tindakan yang tidak diharapkan, misalnya saja memperoleh nilai yang baik dengan cara menyontek. Hal ini dapat dipengaruhi oleh beberapa hal, salah satu diantaranya adalah tingkat percaya diri yang merupakan aspek pribadi yang melekat pada diri individu itu sendiri. Individu yang memiliki latar belakang yang mendukung akan memperoleh tingkat percaya diri yang tinggi sehingga mampu bersosialisasi dengan baik.

Percaya diri atau self confidence adalah aspek kepribadian yang penting pada diri seseorang. Tanpa adanya kepercayaan diri maka akan banyak menimbulkan masalah pada diri seseorang. Kepercayaan diri merupakan atribut yang paling berharga pada diri seseorang dalam kehidupan bermasyarakat, karena dengan adanya kepercayaan diri, seseorang mampu mengaktualisasikan segala potensi yang ada di dalam dirinya. Sifat percaya diri ini juga dapat dipengaruhi oleh kemampuan dan keterampilan yang dimiliki.

Mahasiswa yang memiliki sifat percaya diri yang tinggi akan mudah berinteraksi dengan mahasiswa lainnya, mampu mengeluarkan pendapat tanpa ada keraguan dan menghargai pendapat orang lain, mampu bertindak dan berpikir postif dalam pengambilan keputusan, sebaliknya mahasiswa yang memiliki kepercayaan diri yang rendah akan sulit untuk berkomunikasi, berpendapat, dan akan merasa bahwa dirinya tidak dapat menyaingi mahasiswa yang lain. Perbedaan tingkat percaya diri yang dimiliki individu tentu akan mempengaruhi perolehan prestasi belajar. Individu yang memiliki percaya diri yang tinggi akan memperoleh prestasi yang baik karena selalu beranggapan positif dan percaya terhadap kemampuan diri sendiri. Begitupun sebaliknya, individu yang memiliki percaya diri yang rendah akan memiliki prestasi 
belajar yang kurang memuaskan karena selalu beranggapan negatif dan tidak percaya akan kemampuan dan potensi yang dimilikinya.

Penelitian yang dilakukan oleh (Syam \& Amri, 2017) yang berjudul Pengaruh Kepercayaan Diri (self confidence) Berbasis Kaderisasi IMM Terhadap Prestasi Belajar. Hal ini menunjukkan bahwa terjadi hubungan yang cukup erat antara kepercayaan diri (self confidence) berbasis Kaderisasi IMM terhadap prestasi belajar mahasiswa. Sedangkan angka R2 (R Square) sebesar 0,941 atau $(94,1 \%)$. Hal ini menunjukkan bahwa presentase sumbangan kepercayaan diri (self confidence) terhadap prestasi belajar mahasiswa sebesar $94,1 \%$ sedangkan sisanya sebesar 6,6\% dipengaruhi atau dijelaskan oleh variabel lain yang tidak dimasukkan dalam penelitian ini. Dapat disimpulkan bahwa terdapat pengaruh positif yang signifikan (sig. < 0,05) antara kepercayaan diri (self confidence) berbasis Kaderisasi IMM terhadap prestasi belajar mahasiswa Program Studi Pendidikan Biologi Angkatan 2014 FKIP UMPAR.

Pendapat yang sama juga disampaikan (Patmawati, Saleh, \& Syahrul, 2018) yang berjudul Efektifitas Metode Pembelajaran Klinik Terhadap Kemampuan Berpikir Kritis dan Kepercayaan Diri Mahasiswa Keperawatan. Dengan kesimpulan bahwa metode pembelajaran yang dapat berpengaruh terhadap kemampuan berpikir kritis dan kepercayaan diri mahasiswa keperawatan diantaranya adalah konferensi klinis, simulasi, demonstrasi model, peta konsep dan ronde keperawatan, oleh karena itu pembimbing klinik harus mengetahui dengan baik metode pembelajaran yang akan digunakan, agar dapat memilih metode pembelajaran yang tepat dalam pembimbingan khususnya di lingkungan klinik.

Berdasarkan hasil penelitian (Fitri \& Nelwati, 2020) bahwa sebanyak 62\% mahasiswa lebih banyak mengalami tingkat kecemasan dan kurang percaya diri rendah, sebanyak $68 \%$ mengalami kekhawatiran selama dalam pembelajaran klinik. Kecemasan dan kurang percaya diri dan kekhawatiran disebabkan oleh kurangnya bimbingan serta dukungan dari perawat ruangan dalam membantu mahasiswa mempelajari keterampilan selama praktik di rumah sakit dengan prosentase sebanyak 63\%. Hasil penyebaran angket dan wawancara yang dilakukan di Akper Dirgahayu Samarinda pada bulan september 2016 diperoleh data bahwa sebanyak 19,2\% mahasiswa merasa cemas dan belum siap untuk praktik di klinik karena belum mendapatkan gambaran tentang bagaimana praktik klinik dan belum pernah praktik di rumah sakit sebelumnya.

Sedangkan hasil pendahuluan yang penulis lakukan dengan wawancara pada mahasiswa pilihan yang masuk dalam kelompok Cerdas dan akan menjalankan praktik klinik di SMC RS Telogorejo 62\% mahasiswa mengatakan kepercayaan diri dalam pembelajaran klinik dalam kondisi sedang hal tersebut dikarenakan kecemasan, kurang percaya diri saat di depan pasien baik saat berkomunikasi dengan pasien maupun saat menjalankan asuhan keperawatan (Diklat SMC RS Telogorejo, 2019). Berdasarkan penelitian dan wawancara didapatkan data yang berbeda dari penelitian terdahulu dikatakan bahwa anak cerdas istimewa memiliki tingkat kepercayaan tingi dan memiliki cara berpikir yang diatas rata- rata mahasiswa biasa, dapat berpikir kritis lebih cepat. Dalam wawancara dengan mahasiswa pilihan yang menjalankan praktik di SMC RS 
Telogorejo didapatkan mahasiswa tersebut memiliki kepercayaan diri yang sedang dan cenderung mahasiswa tersebut mengatakan memilki kecemasan saat akan berkomunikasi dengan pasien pada saat mereka menjalankan praktik klinik.

Saat ini litertur yang membahas tentang kepercayaan diri mahasiswa cerdas istimewa khususnya pada pembelajaran klinik belum banyak dilakukan sehingga perlu adanya penambahan litertur untuk menambah kajian. Berdasarkan uraian tersebut, maka reviewer ingin mengidentifikasi bagaimana kepercayaan diri (self Confidence) pada mahasiswa cerdas istimewa dan pengaruh yang ditimbulkannya dalam pembelajaran klinik. Tujuan dari penelitian ini adalah untuk menganalisa penelitian-penelitian sebelumnya tentang kepercayaan diri mahasiswa cerdas istimewa.

\section{Metode Penelitian}

Metode yang digunakan dalam penulisan ini adalah studi literature review. Artikel yang digunakan adalah artikel dari proses pencarian website Sciene Direct, PumMeds, SAGE dan google scola. Artikel yang digunakan adalah 27 artikel yang diterbitkan enam tahun terakhir. Pencarian artikel dengan mengumpulkan tema mahasiswa cerdas istimewa dikaitkan dengan kepercayaan diri pada pembelajaran klinik yang kemudian dilakukan penyaringan untuk mengidentifikasi literatur. Pembatasan dilakukan terkait tahun dan tema. Tahun terbit yang digunakan adalah tahun 2015 sampai 2020. Kata kunci yang diguankan adalah "Kepercayaan Diri (self confidence), Mahasiswa Cerdas Istimewa, Pembelajaran Klinik.

\section{Hasil dan Pembahasan}

Berdasarkan artikel-artikel yang telah dianalisis, kepercayaan diri pada mahasiswa cerdas istimewa berpengaruh terhadap pembelajaran mahasiswa tersebut saat di lahan klinik. Berikut hasil analisis artikel-artikel penelitian sebelumnya:

Tabel 1

Ringkasan artikel tentag kepercayaan diri mahasiswa cerdas istimewa

\begin{tabular}{|c|c|c|c|c|c|}
\hline No. & Penulis & Tahun & Desain & $\begin{array}{c}\text { Sampe } \\
1\end{array}$ & Hasil \\
\hline 1. & $\begin{array}{l}\text { (Nursapti } \\
\text { ni, } \\
\text { Syazali, } \\
\text { Sobri, } \\
\text { Sutisna, } \\
\& \\
\text { Widodo, } \\
\text { 2020) }\end{array}$ & 2020 & Statistik Diskriptif & 66 & $\begin{array}{lr}\text { Hasil dari } & \text { penelitian ini } \\
\text { adalah } & \text { pengaruh } \\
\text { kepercayaan } & \text { diri sangat } \\
\text { tinggi } & \text { dibandingkan } \\
\text { komunikasi } & \text { orangtua } \\
\text { terhadap } & \text { kemandirian } \\
\text { belajar mahasiswa }\end{array}$ \\
\hline 2. & $\begin{array}{l}\text { (Suastini, } \\
\text { 2019) }\end{array}$ & 2019 & Diskriptif Analisis & 31 & $\begin{array}{lr}\text { Hasil } & \text { penelitian } \\
\text { menunjukkan } & \text { bahwa } \\
\text { kepercayaan } & \text { diri siswa } \\
\text { dalam } & \text { pembelajaran } \\
\text { matematika } & \text { mengalami }\end{array}$ \\
\hline
\end{tabular}




\begin{tabular}{|c|c|c|c|c|c|}
\hline & & & & & $\begin{array}{l}\text { peningkatan, Peningkatan } \\
\text { ini terjadi karena berbagai } \\
\text { tindakan yang telah } \\
\text { dilakukan oleh guru yaitu: } \\
\text { kegiatan pembelajaran } \\
\text { berpusat pada siswa sehinga } \\
\text { siswa memiliki } \\
\text { tanggungjawab yang besar } \\
\text { dalam proses pembelajaran }\end{array}$ \\
\hline 3. & $\begin{array}{l}\text { (Sriatika, } \\
\text { 2019) }\end{array}$ & 2019 & $\begin{array}{l}\text { Metode penelitian } \\
\text { yang digunakan } \\
\text { berbentuk pre } \\
\text { experimental design } \\
\text { dengan mengunakan } \\
\text { teknik purposive } \\
\text { sampling dan teknik } \\
\text { pengumpulan data } \\
\text { berupa angket serta } \\
\text { desain penelitian yang } \\
\text { digunakan adalah one } \\
\text { group pres-test } \\
\text { post-test design. }\end{array}$ & 30 & 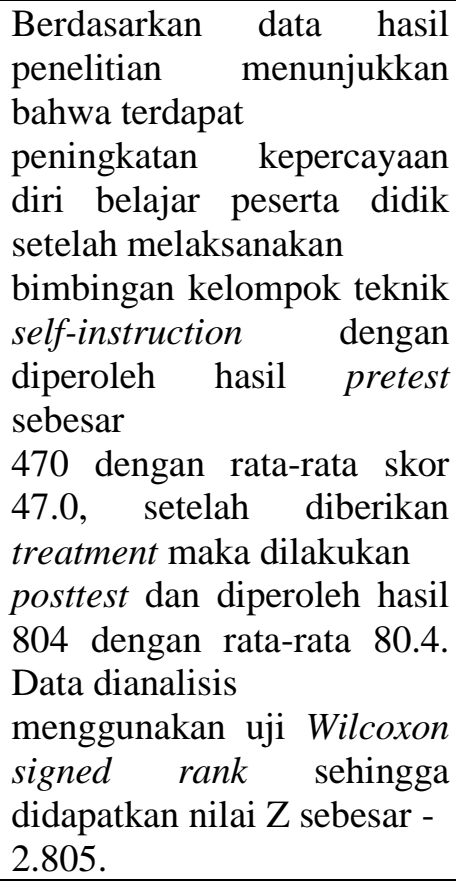 \\
\hline 4. & $\begin{array}{l}\text { (Makaria } \\
\text { Rachman } \\
\text { \&achmay } \\
\text { Rachr } \\
\text { anie, } \\
2019)\end{array}$ & 2019 & $\begin{array}{l}\text { Data penelitian } \\
\text { dikumpulkan } \\
\text { menggunakan skala } \\
\text { likert efikasi diri } \\
\text { akademik dan } \\
\text { kepercayaan diri }\end{array}$ & $\begin{array}{c}102 \\
\text { Mahas } \\
\text { iswa } \\
\text { Unive } \\
\text { rsitas } \\
\text { Mang } \\
\text { kurat }\end{array}$ & $\begin{array}{l}\text { Hasil penelitian adalah } \\
\text { terdapat korelasi positif } \\
\text { antara kepercayaan diri dan } \\
\text { efikasi diri akademik } \\
\text { mahasiswa Program Studi } \\
\text { Bimbingan dan Konseling } \\
\text { Universitas Lambung } \\
\text { Mangkurat angkatan } 2018 \text {. } \\
\text { Semakin bagus atau tinggi } \\
\text { efikasi diri akademik yang } \\
\text { dimiliki mahasiswa maka } \\
\text { akan semakin tinggi pula } \\
\text { kepercayaan dirinya dalam } \\
\text { menyelesaikan semua tugas- } \\
\text { tugas akademik. Hasil } \\
\text { penelitian ini bisa menjadi } \\
\text { data pendukung bagi } \\
\text { penelitian sejenis, yang } \\
\text { membuktikan an bahwa } \\
\text { terdapat korelasi antara } \\
\text { kepercayaan diri dan efikasi } \\
\text { diri akademik }\end{array}$ \\
\hline 5. & (Eva \& & 2016 & Wawancara & 3 & Kesimpulan yang didapat \\
\hline
\end{tabular}




\begin{tabular}{|c|c|c|c|c|c|}
\hline & $\begin{array}{l}\text { Bisri, } \\
\text { 2018) }\end{array}$ & & $\begin{array}{l}\text { Ibu yang memiliki } \\
\text { anak cerdas istimewa }\end{array}$ & & $\begin{array}{lr}\begin{array}{l}\text { secara umum } \\
\text { menggambarkan }\end{array} & \text { subyek } \\
\text { anak cerdas } & \text { istimewa } \\
\text { menunjukkan adanya } & \\
\text { lompatan perkembangan } \\
\text { kognitif dan kepribadian }\end{array}$ \\
\hline 6. & $\begin{array}{l}\text { (Arum, } \\
2019)\end{array}$ & 2019 & $\begin{array}{l}\text { Dokumentasi dan } \\
\text { skala psikologi }\end{array}$ & $\begin{array}{l}32 \\
\text { siswa } \\
\text { cerdas } \\
\text { istime } \\
\text { wa }\end{array}$ & $\begin{array}{l}\begin{array}{l}\text { Hipotesis yang } \\
\text { adalah tidak }\end{array} \begin{array}{r}\text { diajukan } \\
\text { terdapat } \\
\text { kecerdasan }\end{array} \\
\text { hubungan } \\
\text { intelegensi istimewa dengan } \\
\text { motivasi berprestasi di kelas } \\
\text { Cerdas Istimewa (CI). Data } \\
\text { dalam penelitian ini } \\
\text { dianalisis menggunakan } \\
\text { teknik korelasi spearman } \\
\text { rho dengan bantuan SPSS } \\
\text { 17.00 For Window. Hasil } \\
\text { dari penelitian data } \\
\text { menunjukkan tidak ada } \\
\text { hubungan antara kecerdasan } \\
\text { intelegensi istimewa dengan } \\
\text { motivasi berprestasi siswa } \\
\text { cerdas istimewa (CI) } \\
\text { dengan nilai koefisien } \\
\text { sebesar } \mathrm{r}=-0,109 \text { dengan } \\
\text { taraf signifikan } \mathrm{p}=0,544 .\end{array}$ \\
\hline 7. & $\begin{array}{l}\text { (Rasandi, } \\
\text { Putri, } \\
\text { Tiara, } \\
\text { 2018) }\end{array}$ & 2018 & Studi Diskriptif & 57 & $\begin{array}{lr}\text { Hasi Penelitian } & \text { bahwa } \\
\text { kepercayaan diri } & \\
\text { dipengaruhi oleh } 4 & \text { aspek } \\
\text { yaitu aspek keyakinan } \\
\text { kemampuan diri dalam } \\
\text { berbicara } \\
\text { mengendalikan dikelas, } \\
\text { bertanya, dan prokrastinasi }\end{array}$ \\
\hline 8. & $\begin{array}{l}\text { (Syam \& } \\
\text { Amri, } \\
\text { 2017) }\end{array}$ & 2017 & $\begin{array}{c}\text { Analisis statistik } \\
\text { deskriptif dan analisis } \\
\text { statistik inferensial. }\end{array}$ & 52 & $\begin{array}{l}\text { Berdasarkan hasil penelitian } \\
\text { dan pembahasan, } \\
\text { kepercayaan diri (self } \\
\text { confidence) berbasis } \\
\text { Kaderisasi IMM mahasiswa } \\
\text { di } \\
\text { Program Studi Pendidikan } \\
\text { Biologi Angkatan } 2014 \\
\text { berada dalam kategori } \\
\text { cukup, belajar mahasiswa } \\
\text { prestasi belaj } \\
\text { mahasiswa di Program } \\
\text { Studi Pendidikan Biologi } \\
\text { Angkatan 2014 berada } \\
\text { dalam kategori sangat } \\
\text { memuaskan sedangkan } \\
\text { kepercayaan } \\
\text { diri self confidence) }\end{array}$ \\
\hline
\end{tabular}




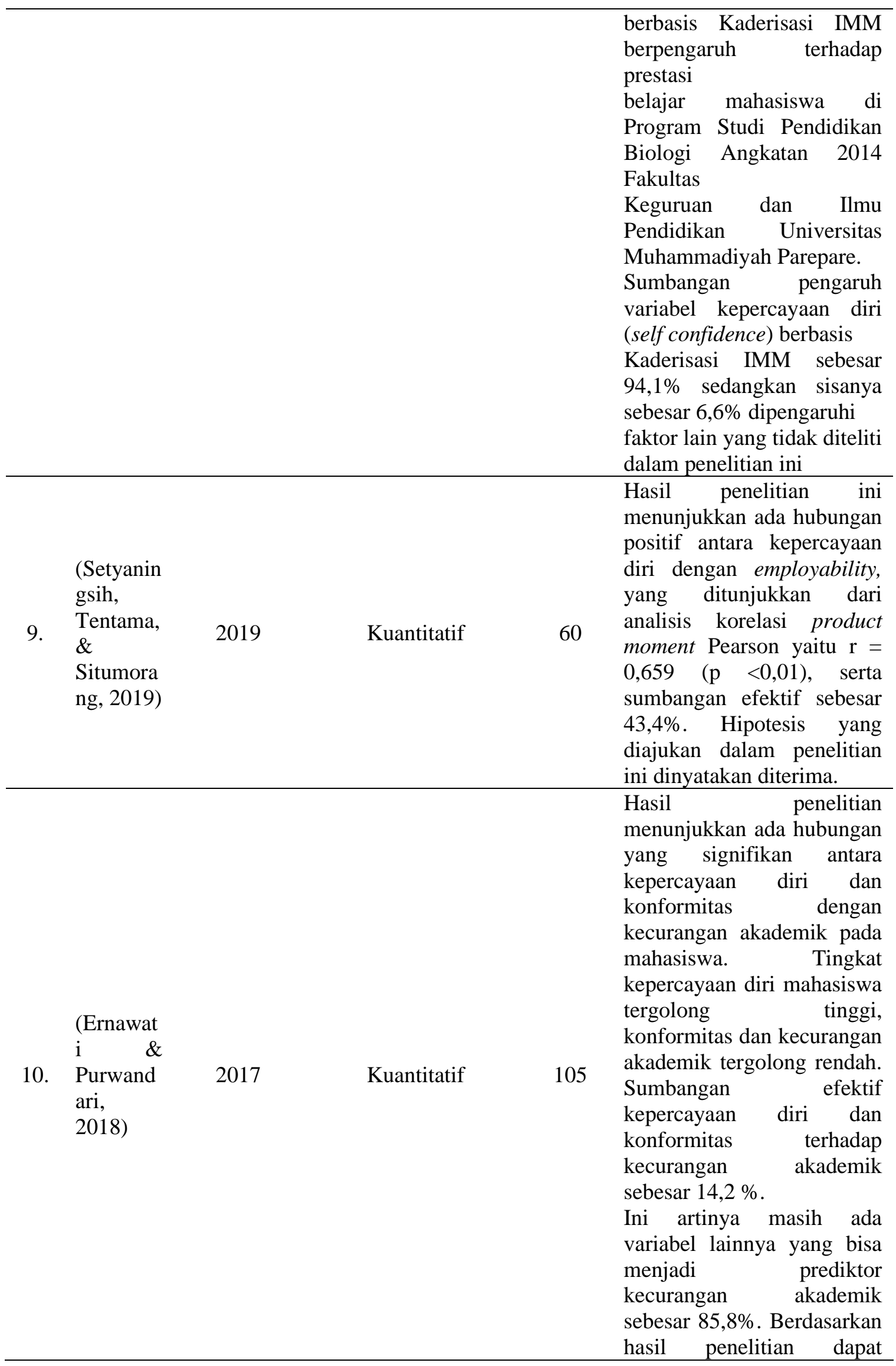




\begin{tabular}{|c|c|c|c|c|c|}
\hline & & & & & $\begin{array}{lr}\text { disimpulkan bahwa terdapat } \\
\text { hubungan antara } \\
\text { kepercayaan diri dan } \\
\text { konformitas dengan } \\
\text { kecurangan akademik pada } \\
\text { mahasiswa }\end{array}$ \\
\hline 11. & $\begin{array}{l}\text { (Budiani, } \\
\text { Mulyana, } \\
\& \\
\text { Puspitad } \\
\text { ewi, } \\
\text { 2020) }\end{array}$ & 2020 & $\begin{array}{c}\text { kuantitatif } \\
\text { korelasional. }\end{array}$ & 30 & 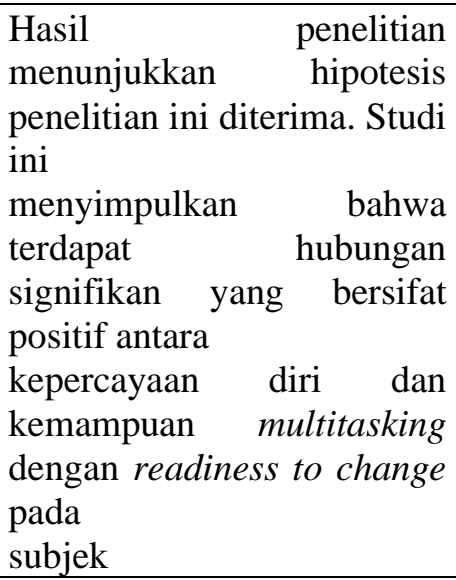 \\
\hline 12. & $\begin{array}{l}\text { (Prasetya } \\
\& \\
\text { Wijayant } \\
\mathrm{i}, 2019 \text { ) }\end{array}$ & 2019 & $\begin{array}{l}\text { deskriptif survey } \\
\text { menggunakan } \\
\text { kuesioner academic } \\
\text { behavioural } \\
\text { confidence scale }\end{array}$ & 191 & $\begin{array}{l}\text { Temuan hasil penelitian } \\
\text { menunjukkan bahwa } \\
\text { kepercayaan diri akademik } \\
\text { pada mahasiswa } \\
\text { keperawatan adalah tinggi } \\
\text { dengan rata-rata } 3,73 \text { diatas } \\
\text { nilai median 3,71. Hal ini } \\
\text { menunjukkan bahwa nilai } \\
\text { kepercayaan diri akademik } \\
\text { mahasiswa keperawatan } \\
\text { adalah tinggi dikarenakan } \\
\text { nilai mean berada diatas } \\
\text { nilai median. Penelitian ini } \\
\text { dapat disimpulkan bahwa } \\
\text { rata-rata nilai kepercayaan } \\
\text { diri akademik mahasiswa } \\
\text { keperawatan adalah tinggi. } \\
\text { Penelitian ini menyarankan } \\
\text { untuk penelitian lainnya } \\
\text { supaya lebih menggali } \\
\text { faktor-faktor yang } \\
\text { mempengaruhi kepercayaan } \\
\text { diri akademik. }\end{array}$ \\
\hline 13. & $\begin{array}{l}\text { (Patmaw } \\
\text { ati et al., } \\
\text { 2018) }\end{array}$ & 2018 & Artikel Review & 10 & $\begin{array}{l}\text { Metode pembelajaran yang } \\
\text { dapat berpengaruh terhadap } \\
\text { kemampuan berpikir kritis } \\
\text { dan kepercayaan diri } \\
\text { mahasiswa keperawatan } \\
\text { diantaranya adalah } \\
\text { konferensi } \\
\text { klinis, simulasi, demonstrasi } \\
\text { model, peta konsep } \\
\text { dan ronde keperawatan, }\end{array}$ \\
\hline
\end{tabular}




\begin{tabular}{|c|c|c|c|c|c|}
\hline & & & & & $\begin{array}{l}\text { oleh karena itu pembimbing } \\
\text { klinik harus mengetahui } \\
\text { dengan baik metode } \\
\text { pembelajaran } \\
\text { yang akan digunakan, agar } \\
\text { dapat memilih } \\
\text { metode pembelajaran yang } \\
\text { tepat dalam pembimbingan } \\
\text { khususnya di lingkungan } \\
\text { klinik. }\end{array}$ \\
\hline 14. & $\begin{array}{l}\text { (Regar, } \\
\text { Syahrul, } \\
\text { \& Tahir, } \\
\text { 2019) }\end{array}$ & 2019 & Pilot study & 20 & $\begin{array}{l}\text { Instrumen kinerja } \\
\text { preceptor, Kepuasan, } \\
\text { Kepercayaan diri dan } \\
\text { Critical Thinking preceptee } \\
\text { memiliki struktur kata dan } \\
\text { internal konsistensi yang } \\
\text { baik. Implikasinya dalam } \\
\text { keperawatan menyediakan } \\
\text { instrumen yang bisa } \\
\text { digunakan dalam menilai } \\
\text { kinerja preceptor, kepuasan, } \\
\text { kepercayaan diri dan crit- } \\
\text { ical thinking preceptee } \\
\text { dalam melaksanakan praktik } \\
\text { klinik. Dengan adanya } \\
\text { evaluasi terhadap kinerja } \\
\text { preceptor diharapkan akan } \\
\text { meningkatkan kinerjanya } \\
\text { dalam melakukan } \\
\text { pembimbingan klinik seh- } \\
\text { ingga peserta didik menjadi } \\
\text { puas, percaya diri dan } \\
\text { meningkat kemampuan } \\
\text { berpikir kritisnya dalam } \\
\text { melaksanakan praktik } \\
\text { keperawatan }\end{array}$ \\
\hline 15. & $\begin{array}{l}\text { (Utami, } \\
\text { Syaudah, } \\
\& \\
\text { Panggab } \\
\text { ean, } \\
2017 \text { ) }\end{array}$ & 2017 & $\begin{array}{l}\text { One-Group Pretest- } \\
\text { Postest Design }\end{array}$ & 10 & $\begin{array}{l}\text { Kesimpulan dari penelitian } \\
\text { eksperimen ini } \\
\text { adalah kapsul motivasi } \\
\text { mampu meningkatkan } \\
\text { rasa percaya diri.Terlihat } \\
\text { ada peningkatan nilai } \\
\text { dari angket pretest dan } \\
\text { posttest yang diberikan } \\
\text { pada subjek. }\end{array}$ \\
\hline 16. & $\begin{array}{l}\text { Milfayet } \\
\text { ty \& } \\
\text { Hajar, } \\
\text { 2019) }\end{array}$ & 2019 & $\begin{array}{l}\text { Metodenya adalah } \\
\text { workshopdengan } \\
\text { teknik creative art. }\end{array}$ & 30 & $\begin{array}{lr}\text { Hasil pendampingan } \\
\text { menunjukkan bahwa guru } \\
\text { yang mengajar di kelas } \\
\text { akselerasi dapat memetakan } \\
\text { masalah } \\
\text { merencanakan siswa, } \\
\text { melaksanakan pembelajaran }\end{array}$ \\
\hline
\end{tabular}




\begin{tabular}{|c|c|c|}
\hline & & $\begin{array}{lr}\text { akademik } & \text { secara terpadu } \\
\text { dengan teknik kreatif, } & \text { kn dan } \\
\text { melakukan konseling dalami } \\
\text { play therapy } & \text { sederhana. } \\
\text { Siswa yang } & \text { mengalami } \\
\text { masalah } & \text { dalam } \\
\text { pengendalian } & \text { diri, } \\
\text { agressivitas, masalah emosi } \\
\text { dan masalah sosial menjadi } \\
\text { berkurang. Berdasarkan } \\
\text { hasil ini dikemukakan } \\
\text { bahwa penguatan } \\
\text { kemampuan guru dalam } \\
\text { melaksanakan pembelajaran } \\
\text { akademik terpadu } \\
\text { pengembangan diri efektif } \\
\text { dalam mengentaskan } \\
\text { masalah perilaku siswa di } \\
\text { SD Percobaan jalan Sei } \\
\text { Petani Medan. }\end{array}$ \\
\hline 17. & $\begin{array}{l}\text { (Rahmah } \\
\text {, 2019) }\end{array}$ & $\begin{array}{l}\text { pembelajaran } \text { matematika } \\
\text { PDCI di SD } \\
\text { Muhammadiyah } \\
\text { Banjarmasin tahun pelajaran } \\
\text { 2019/2020 terdiri dari } \\
\text { perencanaan, pelaksanaan, } \\
\text { dan penilaian. Perencanaan } \\
\text { dan pelaksanaan } \\
\text { pembelajaran } \\
\text { dengan kelas reguler, pada } \\
\text { perencanan perbedaannya } \\
\text { adalah pada kurikulum yang } \\
\text { digunakan, sedangkan pada } \\
\text { pelaksanaan adalah } \\
\text { pengalaman belajar yang } \\
\text { berbeda dalam arti } \\
\text { pendalaman dan percepatan. } \\
\text { Penilaian pembelajaran } \\
\text { sama dengan kelas reguler. } \\
\text { Namun, pada PDCI tidak } \\
\text { ada penilaian tengah } \\
\text { semester (PTS). (2) Minat } \\
\text { belajar PDCI terhadap mata } \\
\text { pelajaran matematika SD } \\
\text { Muhammadiyah } \\
\text { Banjarmasin tahun pelajaran } \\
\text { 2019/2020 berada pada } \\
\text { kategori sangat tinggi. Hasil } \\
\text { aspek minat belajar yang } \\
\text { sangat mempengaruhi } \\
\text { adalah aspek keterlibatan } \\
\text { peserta didik dalam belajar }\end{array}$ \\
\hline
\end{tabular}


Setelah menganalisa dari 17 jurnal diatas dapat disimpulkan bahwa jurnal - jurnal yang telah diteliti oleh peneliti-peneliti sebelumnya keseluruhannya membahas tentang kepercayaan diri pada mahasiswa cerdas istimewa. Sedangkan perbedaan dari 17 jurnal diatas dapat dilihat sebagai berikut untuk 11 jurnal menjelaskan tentang kepercayaan diri siswa cerdas istimewa pada bidang-bidang tertentu contohnya kepercayaan diri siswa cerdas istimewa pada bidang matematika, kepercayaan diri siswa cerdas istimewa pada biologi, kepercayaan diri siswa cerdas istimewa kemapuan berbicara atau berkomunikasi dan multitalksting, kepercayaan diri siswa cerdas istimewa cara berpikir kritis dan kepercayaan diri siswa cerdas istimewa dengan motivasi diri, dan jurnal yang lain membahas kepercayaan diri pada pembelajaran klinik, bimbingan konseling pada siswa cerdas istimewa.

Pada penelitian (Eva \& Bisri, 2018) pada ibu yang memiliki anak cerdas istimewa didapatkan hasil secara umum anak cerdas istimewa menunjukkan adanya lompatan perkembangan kognitif dan kepribadian hal ini sejalan dengan yang disampaikan (Van Tiel, 2015) yang mengatakan bahwa siswa cerdas istimewa cenderung memiliki prestasi-prestasi yang luar biasa di banding anak yang bukan dari karakter cerdas istimewa. Namun terlepas dari itu perlu adanya motivasi dan metode-metode yang tepat sasaran untuk membimbing anak cerdas istimewa di lihat dari sisi kognitif dan sisi kepribadiannya. Dengan demikian harapan bahwa anak cerdas istimewa di tangan ibu, pendidik pembimbing yang tepat akan melahirkan kualitas anak cerdas istimewa yang luar biasa.

Pada penelitia (Sriatika, 2019) dan penelitian (Makaria et al., 2019) pada anak cerdas istimewa mengenai kepercayaan diri dihasilkan dalam penelitiannya ada peningkatan kepercayaan diri pada anak cerdas istimewa dengan bimbingan self inctruction hal tersebut bertolak belakang dengan pebelitian (Syafrudin \& Nawangsasi, 2019) didalam penelitiannya menyimpulka bahwa anak cerdas istimewa terkadang memiliki hambatan dalam perkembangan sosio-emosionalnya merasarendah diri, tidak dapat bergau dan menyesuaikan diri dengan teman-temannya karena wawasanya tidak sesuai dengan teman-teman yang bukan dari kalangan cerdas istimewa. Oleh karena itu dibutuhkan orang-orang dewasa yang ada disekitarnya untuk dapat mengarahkan dan memfasilitasi hubungan dari anak cerdas istimewa tersebut ke arah yang lebih positif.

Pada penelitian (Regar et al., 2019) terkait kepercayaan diri yang meningkat dengan adanya pendamping yang memberikan nilai positif bagi anak bimbingannya terlihat jelas bahwa ada hubungan yang positif antara proses bimbingan efektif dengan kepercayaan diri yang diperoleh pada anak cerdas istimewa dimanapun berada terutama pada proses pembelajaran teori maupun saat pembelajaran praktek. Saat pembelajaran praktik saat anak cerdas istimewa mendapatkan mentor atau pembimbing yang mampu membimbing dengan baik sesuai karakteristik anak cerdas istimewa didapatkan inovasiinovasi pada pembelajaran itu sendiri sehingga terdapat hubungan timbal balik antara pembimbing dengan anak cerdas istimewa tersebut karena adanya kepercayaan diri yang kuat dan kemapuan berpikir kritis. 
Hasil kajian literatur menunjukkan bahwa kecerdasan intelegensi istimewa adalah suatu kemampuan yang ditandai oleh perbuatan yang cepat dan tepat, melibatkan proses berpikir secara rasional dan kemampuan untuk menggunakan daya pikir tersebut dalam memahami situasi yang baru serta dalam mengambil kesimpulan atau tindakan yang lain dari pada yang lain serta bahwa anak cerdas istimewa menunjukkan adanya lompatan perkembangan kognitif dan kepribadian. Pada mahasiswa cerdas istimewa terdapat fenomena yang menggambarkan bahwa kesejahteraan psikologis mahasiswa cerdas istimewa belum berkembang dengan baik. Ketidakmampuan mengontrol lingkungan menyebabkan mahasiswa cerdas istimewa terbawa oleh lingkungan. Hal ini menyebabkan prestasi mahasiswa cerdas istimewa menjadi fluktuatif dan tidak mampu membuat keputusan tanpa dukungan teman-teman yang bersamanya.

\section{Kesimpulan}

Mahasiswa cerdas istimewa masih banyak yang memiliki kondisi psikologis yang sangat perlu kita perhatikan contohnya emosi, kepercayaan diri, hubungan sosial dengan teman sebaya karena itu mahasiswa cerdas istimewa sangat membutuhkan pendidikan khusus, kesempatan berkerjasama, dan pendampingan khusus. Pendampingan dapat dengan cara memetakan masalah siswa, merencanakan dan melaksanakan pembelajaran terpadu dengan teknik kreatif, melakukan konseling dan play therapy. Dari analisa diatas kepercayaan diri pada mahasiswa istimewa dipengaruhi oleh 4 aspek yaitu aspek keyakinan kemampuan diri dalam berbicara dikelas, mengendalikan ganget, bertanya, dan prokrastinasi.

Pada mahasiswa cerdas istimewa yang belajar di lahan klinik yang memilki kepercayaan tinggi, hal tersebut didukung dengan berbagai metode pembelajaran yang dapat berpengaruh terhadap kemampuan berpikir kritis dan kepercayaan diri mahasiswa keperawatan diantaranya adalah konferensi klinis, simulasi, demonstrasi model, peta konsep dan ronde keperawatan, oleh karena itu pembimbing klinik harus mengetahui dengan baik metode pembelajaran yang akan digunakan, agar dapat memilih metode pembelajaran yang tepat dalam pembimbingan khususnya di lingkungan klinik.

Mahasiswa cerdas istimewa cenderung mempunyai masalah psikologis lebih sedikit daripada teman sebayanya. Jika individu lebih sedikit mempunyai masalah psikologis maka diasumsikan individu tersebut lebih sejahtera secara psikologis. (Eva \& Bisri, 2018) menjelaskan bahwa indikator rendah kesejahteraan psikologis adalah adanya masalah psikologis, seperti, rendahnya kepercayaan diri, kecemasan, depresi, penyimpangan perilaku, dan gangguan psikiatris. Ketidakmampuan mengontrol lingkungan menyebabkan mahasiswa cerdas istimewa terbawa oleh lingkungan. Hal ini menyebabkan prestasi mahasiswa cerdas istimewa menjadi fluktuatif dan tidak mampu membuat keputusan tanpa dukungan teman-teman yang bersamanya.

Dalam pendidikan keperawatan keyakinan/confidence merupakan variabel penting. Mahasiswa dengan tingkat kepercayaan diri yang lebih tinggi memiliki kemungkinan lebih besar untuk mengembangkan intervensi yang berhasil, karena mereka mampu menguji dan menggunakan kompetensinya dengan lebih mudah. Dalam 
Nofita Veronika, Rini Sugiarti dan Erwin Erlangga

literatur ini memilki kelemahan yaitu belum banyak literasi tentang pembelajaran klinik pada anak cerdas istimewa untuk itu diharapkan untuk penelitian berikutnya lebih difokuskan pada kepercayaan diri mahasiswa cerdas istimewa di lingkungan pembelajaran klinik. 


\section{BIBLIOGRAFI}

Arum, Rara Puspita. (2019). Hubungan Antara Kecerdesan Intelegensi Istimewa Dengan Motivasi Berprestasi Siswa Di Kelas Cerdas Istimewa (CI) SMA Negeri 8 Pekanbaru. Universitas Islam Negeri Sultan Syarif Kasim Riau. Google Scholar

Asiyah, Asiyah, Walid, Ahmad, \& Kusumah, Raden Gamal Tamrin. (2019). Pengaruh Rasa Percaya Diri Terhadap Motivasi Berprestasi Siswa pada Mata Pelajaran IPA. Scholaria: Jurnal Pendidikan Dan Kebudayaan, 9(3), 217-226. Google Scholar

Budiani, Meita Santi, Mulyana, Olievia Prabandini, \& Puspitadewi, Ni Wayan Sukmawati. (2020). Peran Kepercayaan Diri dan Kemampuan Multitasking terhadap Readiness to Change pada Mahasiswa. Jurnal Psikologi Teori Dan Terapan, 10(2), 150-162. Google Scholar

Diklat SMC RS Telogorejo. (2019). Diklat SMC RS Telogorejo. Semarang.

Ernawati, Sri, \& Purwandari, Eny. (2018). Kecurangan Akademik Pada Mahasiswa Ditinjau Dari Kepercayaan Diri Dan Konformitas. Universitas Muhammadiyah Surakarta. Google Scholar

Eva, Nur, \& Bisri, Moh. (2018). Kesejahteraan Psikologis Siswa Cerdas Istimewa. Karya Dosen Fakultas Ilmu Psikologi. Google Scholar

Fitri, Muri Juliani, \& Nelwati, Sasmi. (2020). Pelaksanaan Layanan Penguasaan Konten Dalam Meningkatkan Motivasi Belajar Peserta Didik Di SMP Negeri 1 PAINAN. Jurnal Al-Taujih: Bingkai Bimbingan Dan Konseling Islami, 6(2), 148-156. Google Scholar

Hsu, Li Ling, Hsieh, Suh Ing, Chiu, Hsiu Win, \& Chen, Ya Lin. (2014). Clinical teaching competence inventory for nursing preceptors: instrument development and testing. Contemporary Nurse, 46(2), 214-224. Google Scholar

Indriawati, Prita. (2018). Pengaruh Kepercayaan Diri Dan Kecerdasan Emosional Terhadap Hasil Belajarmahasiswafkip Universitas Balikpapan. Jurnal Dimensi, 7(1), 59-77. Google Scholar

Mahanani, Srinalesti, Dewi, Yulis Setiya, \& Soeratri, Widji. (2014). Analisis Kinerja Perawat Pembimbing Klinik dengan pendekatan teori kinerja dan Indikator Kompetensi. Jurnal Ners, 9(2), 329-338. Google Scholar

Makaria, Eklys Cheseda, Rachman, Ali, \& Rachmayanie, Ririanti. (2019). Korelasi Kepercayaan Diri dan Efikasi Diri Akademik Mahasiswa Program Studi Bimbingan Dan Konseling Angkatan 2018. JKI (Jurnal Konseling Indonesia), 5(1), 1-5. Google Scholar

Milfayetty, Sri, \& Hajar, Ibnu. (2019). Memberi Penguatan Kepada Guru Dalam Mengatasi Permasalahan pada Anak Cerdas Berbakat di SD Negeri Percobaan Medan. Jurnal Vokasi, 3(2), 90-98. Google Scholar 
Nofita Veronika, Rini Sugiarti dan Erwin Erlangga

Nursalam, Dr. (2014). Manajemen Keperawatan" Aplikasi dalam Praktik Keperawatan Profesional. Salemba Medika. Google Scholar

Nursaptini, Nursaptini, Syazali, Muhammad, Sobri, Muhammad, Sutisna, Deni, \& Widodo, Arif. (2020). Profil Kemandirian Belajar Mahasiswa Dan Analisis Faktor Yang Mempengaruhinya: Komunikasi Orang Tua Dan Kepercayaan Diri. Jurnal Pendidikan Edutama, 7(1), 85-94. Google scholar

Ogurlu, Uzeyir. (2021). Overview of meta-analyses on giftedness. Gifted and Talented International, 1-18. Google scholar

Patmawati, Try Ayu, Saleh, Ariyanti, \& Syahrul, Syahrul. (2018). Efektifitas Metode Pembelajaran Klinik Terhadap Kemampuan Berpikir Kritis Dan Kepercayaan Diri Mahasiswa Keperawatan: A Literature Review. Jurnal Keperawatan Muhammadiyah, 3(2). Google scholar

Pranowo, Taufik Agung. (2019). Analisis Tingkat Motivasi Belajar Siswa di MI Ma'arif Grabag Magelang Jawa Tengah. Indonesian Journal of Guidance and Counseling: Theory and Application, 8(2), 74-80. Google scholar

Prasetya, Aulia Nur, \& Wijayanti, Diyan Yuli. (2019). Gambaran Kepercayaan Diri Akademik Mahasiswa Keperawatan Di Semarang. Google scholar

Rahmah, Anisa. (2019). Minat Belajar Peserta Didik Cerdas Istimewa (PDCI) Terhadap Mata Pelajaran Matematika SD Muhammadiyah 10 Banjarmasin Tahun Pelajaran 2019/2020. Retrieved from https://idr.uinantasari.ac.id/13129/3/AWAL.pdf Google scholar

Rasandi, Putri, Tiara, Dinda. (2018). Tingkat Kepercayaan Diri Mahasiswa Berprestasi Belajar Rendah. Matang, H. A. K., \& Berprestasi, M. A. D. M. Fakultas Psikologi Universitas Sanata Dharma Yogyakarta. Retrieved from https://repository.usd.ac.id/31262/2/141114020_full.pdf

Regar, Maria Jeinny, Syahrul, Syahrul, \& Tahir, Takdir. (2019). Instrumen evaluasi kinerja preceptor dengan kepuasan, kepercayaan diri dan critical thinking preceptee dalam melaksanakan praktik klinik; pilot study. Jurnal Keperawatan Muhammadiyah, 4(2). Google scholar

Setyaningsih, Dwi, Tentama, Fatwa, \& Situmorang, Nina Zulida. (2019). Faktor-faktor yang mempengaruhi employability. Prosiding Seminar Nasional Magister Psikologi Universitas Ahmad Dahlan, 427-432. Google scholar

Sianturi, Wahyuni Apriani. (2020). Berpikir Kritis Untuk Pengambilan Keputusan Dalam Keperawatan. Google scholar

Sriatika. (2019). Pengaruh Bimbingan Kelompok Dengan Teknik Self-Instruction Untuk Meningkatkan Kepercayaan Diri Belajar Peserta Didik Kelas Viii Di Smp Negeri 2 
Kepercayaan Diri (Self Confidence) Mahasiswa Cerdas Istimewa Pada Pembelajaran Klinik

Jati Agung Lampung Selatan Tahun Pelajaran 2019/2020. Universitas Negri Raden Intan Lampung.

Suastini, Ni Putu. (2019). Model Pembelajaran Probing-Promting untuk Meningkatkan Prestasi Belajar Bahasa Inggris. Journal of Education Action Research, 3(4), 366374. Google scholar

Syafrudin, Ulwan, \& Nawangsasi, Devi. (2019). Perkembangan Sosio-Emosional Anak Cerdas Istimewa Di Sekolah Dasar. Google scholar

Syam, Asrullah, \& Amri, Amri. (2017). Pengaruh kepercayaan diri (self confidence) berbasis kaderisasi IMM terhadap prestasi belajar mahasiswa (studi kasus di program studi pendidikan biologi fakultas keguruan dan ilmu pendidikan universitas muhammadiyah parepare). Jurnal Biotek, 5(1), 87-102. Google scholar

Utami, Diah Dinar, Syaudah, Yuni, \& Panggabean, Amestia Prasinata. (2017). "Kapsul Motivasi” Meningkatkan Kepercayaan Diri Mahasiswa. Google scholar

Van Tiel, Julia Maria. (2015). Deteksi dan Penanganan Anak Cerdas Istimewa (Anak Gifted) Melalui Pola Alamiah Tumbuh Kembangnya. Prenada Media. Google scholar

\section{Copyright holder:}

Nofita Veronika, Rini Sugiarti dan Erwin Erlangga (2021)

First publication right:

Journal Syntax Literate

This article is licensed under: 